\title{
Isolation and Characterization of Two New Metabolites from the Sponge-Derived Fungus Aspergillus sp. LS34 by OSMAC Approach
}

\author{
Wei Li ${ }^{1}$, Lijian Ding ${ }^{1, *(1)}$, Ning Wang ${ }^{1}$, Jianzhou Xu ${ }^{1}$, Weiyan Zhang ${ }^{1}$, Bin Zhang ${ }^{1}$, \\ Shan $\mathrm{He}^{1}{ }^{1}$, Bin $\mathrm{Wu}^{2}$ and Haixiao Jin ${ }^{1, *}$ \\ 1 Li Dak Sum Yip Yio Chin Kenneth Li Marine Biopharmaceutical Research Center, College of Food and \\ Pharmaceutical Sciences, Ningbo University, Ningbo 315800, China; 15058882124@163.com (W.L.); \\ wangning2@nbu.edu.cn (N.W.); 15669221063@163.com (J.X.); zhangweiyan@nbu.edu.cn (W.Z.); \\ zhangbin1@nbu.edu.cn (B.Z.); heshan@nbu.edu.cn (S.H.) \\ 2 Ocean College, Zhejiang University, Hangzhou 310058, China; wubin@zju.edu.cn \\ * Correspondence: dinglijian@nbu.edu.cn (L.D.); jinhaixiao@nbu.edu.cn (H.J.); \\ Tel.: +86-574-8760-4388 (L.D.); +86-574-8760-4388 (H.J.)
}

Received: 18 March 2019; Accepted: 10 May 2019; Published: 11 May 2019

\begin{abstract}
The application of an OSMAC (One Strain-Many Compounds) approach on the sponge-derived fungus Aspergillus sp. LS34, using two different media including solid rice medium and potato dextrose broth (PDB) resulted in the isolation and identification of two new compounds, named asperspin A (1) and asperther A (2) along with seven known compounds 3-9. Compounds 1-5 were detected in fungal extracts from rice medium, while compounds 6-9 were isolated from PDB medium. Their structures were unambiguously characterized by HRESIMS and NMR spectroscopic data. The growth inhibitory activity of these compounds against four pathogenic bacteria (Vibrio parahaemolyticus, Vibrio harveyi, Escherichia coli, and Staphylococcus aureus) were evaluated. All the compounds were also tested for their cytotoxicity against seven cancer cell lines, including CCRF-CEM, K562, BGC823, AGS, HCT-116, MDA-MB-453, and COR-L23. Among them, compound 9 showed strong activity against CCRF-CEM and K562 cells with $\mathrm{IC}_{50}$ values of $1.22 \pm 0.05 \mu \mathrm{M}$ and $10.58 \pm 0.19 \mu \mathrm{M}$, respectively. Notably, compound 7 also showed pronounced activity against $S$. aureus with an MIC value of $3.54 \mu \mathrm{M}$.
\end{abstract}

Keywords: OSMAC; fungal natural product; antibacterial; cytotoxic

\section{Introduction}

Marine microorganisms, in particular marine-derived fungi, have proven to be a promising producer of biologically active secondary metabolites for new chemicals in drug discovery [1-5]. Whole genome sequencing of fungi has showed the existence of silent pathways, which are not expressed under standard culture conditions [6]. However, changing culture conditions can activate potentially silent gene clusters thereby increasing the variety of secondary metabolites [7]. The OSMAC (One Strain-Many Compounds) approach has been shown to be a powerful strategy for triggering silent gene clusters by changing different parameters [8]. For example, one successful application was the isolation of novel pimarane diterpenoids from Arctic soil-derived fungus Eutypella sp. D-1, via the modification of the culture medium [9]. In the past decades, sponge-derived fungi in the genus Aspergillus have produced various metabolites, which have displayed biological and pharmacological activities such as antiviral [10], antibacterial [11], antitumor [12], and anti-inflammatory [13,14]. In this work, the OSMAC approach was employed for comparison of the metabolic profiles of the sponge-derived fungus Aspergillus sp. LS34 cultured on PDB medium and solid rice medium, 
respectively. The respective EtOAc extracts obtained from two cultures were analyzed by HPLC, revealing interesting variations in their secondary metabolites. The chromatographic study of these extracts led to two new compounds, including asperspin A (1) and asperther A (2) (isolated from rice medium), together with seven known compounds, diorcinol-3-O- $\alpha$-D-ribofuranoside (3) [15], 4-carbglyceryl-3,3'-dihydroxy-5,5'-dimethyldiphenyl ether (4) [16], gibellulin B (5) [17], daldinin C (6) [18], 12-hydroxysydonic acid (7) [19], (+)-sydonic acid (8) [20], and oxalicumone A (9) [21] (Figure 1). Compounds 3-5 were detected in rice medium, while 6-9 were isolated from PDB medium. Herein we reported the isolation, structure elucidation and biological activities of these compounds.<smiles>COC=CC=Cc1ccc2c(c1CO)OC(C(C)(C)O)C2C</smiles><smiles>Cc1cc(O)cc(Oc2cc(C)c(C(=O)OCC(O)CO)c(O)c2)c1</smiles><smiles>Cc1cc(O)c2c(c1)Oc1c(C)cc(O)c(O)c1O2</smiles><smiles>CC(CO)CCCC(C)(O)c1ccc(C(=O)O)cc1O</smiles><smiles>CC(C)CCCC(C)(O)c1ccc(C(=O)O)cc1O</smiles><smiles>CCC(O)c1ccc2c(c1CO)OC(C(C)(C)O)C2</smiles><smiles></smiles>

Figure 1. Structures of compounds 1-9.

\section{Results and Discussion}

\subsection{Structure Elucidation}

Asperspin A (1) was obtained as a white powder. Its molecular formula was determined as $\mathrm{C}_{16} \mathrm{H}_{22} \mathrm{O}_{4}$ by the negative HRESIMS ion at $m / z 277.1440[\mathrm{M}-\mathrm{H}]^{-}$(calcd. for $\mathrm{C}_{16} \mathrm{H}_{21} \mathrm{O}_{4}, 277.1445$ ), corresponds to 6 degrees of unsaturation. The IR spectrum showed absorption bands for hydroxy $\left(3390 \mathrm{~cm}^{-1}\right)$ and aromatic ring $\left(1645 \mathrm{~cm}^{-1}\right)$ functionalities. The ${ }^{1} \mathrm{H}$ NMR spectrum (Table 1) of 1 displayed the presence of a 1,2,3,4-tetrasubstituted benzene ring $\left[\delta_{\mathrm{H}} 7.05(1 \mathrm{H}, \mathrm{d}, J=7.7 \mathrm{~Hz}, \mathrm{H}-4), 6.98\right.$ $(1 \mathrm{H}, \mathrm{d}, J=7.7 \mathrm{~Hz}, \mathrm{H}-5)]$. The ${ }^{1} \mathrm{H}$ NMR spectrum of $\mathbf{1}$ also showed a methoxy [ $\left.\delta_{\mathrm{H}} 3.39(\mathrm{~s})\right]$, two methyls $\left[\delta_{\mathrm{H}} 1.20(\mathrm{~s}), 1.30(\mathrm{~s})\right]$, three methylenes $\left[\delta_{\mathrm{H}} 4.75(\mathrm{~m}), 4.09(\mathrm{dd}, J=6.0,1.6 \mathrm{~Hz}), 3.15(\mathrm{~m})\right]$, and three methines $\left[\delta_{\mathrm{H}} 6.90(\mathrm{~d}, J=15.7 \mathrm{~Hz}), 6.16(\mathrm{dt}, J=15.7,5.9 \mathrm{~Hz})\right.$, and $\left.4.61(\mathrm{t}, J=9.0 \mathrm{~Hz})\right]$. The ${ }^{13} \mathrm{C} \mathrm{NMR}$ data (Table 1) of 1 contained 16 carbons comprising of six aromatic carbons, three methylenes, three methines, two methyls, a methoxy group and a quaternary carbon. Among them, a benzene ring and two olefinic carbons could be easily identified from the ${ }^{13} \mathrm{C} N M R$, which accounted for five degrees of unsaturation. The remaining one degree of unsaturation was due to the presence of a ring in the structure. The HMBC correlations from $\mathrm{H}-3$ to $\mathrm{C}-3 \mathrm{a}$ and $\mathrm{C}-8 \mathrm{~b}$, from $\mathrm{H}-2$ to $\mathrm{C}-8 \mathrm{~b}$ and $\mathrm{C}-13$ and the $\mathrm{COSY}$ correlation of $\mathrm{H}-2 / \mathrm{H}-3$ indicated the existence of a furan ring fused with a benzene ring through C-3a-C-8b and placed a quaternary carbon at C-13 $\left(\delta_{C} 72.6\right)$ at C-2. Two methyls at C-14 and C-15 were assigned at $\mathrm{C}-13$, by the HMBC correlations of $\mathrm{H}-14$ and $\mathrm{H}-15 / \mathrm{C}-13$, respectively. The substituted hydroxymethylene group C-8 was attached to C-8a, according to the HMBC correlations of $\mathrm{H}-8 / 8 \mathrm{a}$ and 8b. Moreover, the COSY correlations of $\mathrm{H}-6 / \mathrm{H}-9$ and $\mathrm{H}-9 / \mathrm{H}-10$ and the HMBC correlations from $\mathrm{H}-6$ to $\mathrm{C}-10$ and from $\mathrm{H}-10$ to $\mathrm{C}-12$ indicated that 1 possessed a methoxypropylene fragment. Furthermore, the methoxypropylene moiety was positioned at C-5a based on the HMBC correlation of H-9/C-5a. The configuration of the double bond between C- 6 and C-9 was assigned as $E$ form according to a 
NOESY correlation between $\mathrm{H}-6$ and $\mathrm{H}-10$, as well as a large coupling constant of $15.7 \mathrm{~Hz}$. The absolute configuration of the C-2 chiral center in $\mathbf{1}$ was determined to be $R$ by comparing the optical rotation value $\left([\alpha]_{D}^{25}-4.0\right)$ with that of alcohol $[(-)-V]$ previously reported in the literature [22]. Detailed data can be found in Figures S3-S9.

Table 1. ${ }^{1} \mathrm{H}$ and ${ }^{13} \mathrm{C}$ NMR data of compound $1\left(600 \mathrm{MHz}, 150 \mathrm{MHz}\right.$, in $\left.\mathrm{CDCl}_{3}\right)$.

\begin{tabular}{ccc}
\hline Position & $\delta_{\mathbf{C}}$ & $\delta_{\mathbf{H}}(J$ in $\mathbf{H z})$ \\
\hline 2 & 89.8 & $4.61(1 \mathrm{H}, \mathrm{t}, 9.0)$ \\
3 & 30.8 & $3.15(2 \mathrm{H}, \mathrm{m})$ \\
$3 \mathrm{a}$ & 126.7 & \\
4 & 124.5 & $7.05(1 \mathrm{H}, \mathrm{d}, 7.7)$ \\
5 & 119.2 & $6.98(1 \mathrm{H}, \mathrm{d}, 7.7)$ \\
$5 \mathrm{a}$ & 136.3 & \\
6 & 129.4 & $6.90(1 \mathrm{H}, \mathrm{d}, 15.7)$ \\
8 & 56.8 & $4.75(2 \mathrm{H}, \mathrm{m})$ \\
$8 \mathrm{a}$ & 119.5 & \\
$8 \mathrm{~b}$ & 158.6 & \\
9 & 128.5 & $6.16(1 \mathrm{H}, \mathrm{dt}, 15.7,5.9)$ \\
10 & 73.3 & $4.09(2 \mathrm{H}, \mathrm{dd}, 6.0,1.6)$ \\
12 & 58.2 & $3.39(3 \mathrm{H}, \mathrm{s})$ \\
13 & 72.6 & \\
14 & 24.3 & $1.20(3 \mathrm{H}, \mathrm{s})$ \\
15 & 26.4 & $1.30(3 \mathrm{H}, \mathrm{s})$ \\
\hline
\end{tabular}

Asperther A (2) was isolated as a yellow oil. The molecular formula was established as $\mathrm{C}_{19} \mathrm{H}_{22} \mathrm{O}_{8}$ on the basis of the negative HRESIMS ion at $\mathrm{m} / \mathrm{z} 377.1237[\mathrm{M}-\mathrm{H}]^{-}$(calcd. for $\mathrm{C}_{19} \mathrm{H}_{21} \mathrm{O}_{8}, 377.1242$ ), indicating 9 indices of hydrogen deficiency. The IR spectrum showed bands due to hydroxy $\left(3356 \mathrm{~cm}^{-1}\right)$ and aromatic ring $\left(1598 \mathrm{~cm}^{-1}\right)$ functions. The ${ }^{1} \mathrm{H}$ NMR data of 2 (Table 2) displayed the presence of five aromatic $\left[\delta_{\mathrm{H}} 6.29(\mathrm{t}, J=2.2 \mathrm{~Hz}), 6.49(\mathrm{t}, J=1.6 \mathrm{~Hz}), 6.36(\mathrm{~d}, J=2.5 \mathrm{~Hz}), 6.24(\mathrm{~d}, J=2.5 \mathrm{~Hz})\right.$, $6.37(\mathrm{~s})]$, and six aliphatic protons $\left[\delta_{\mathrm{H}} 4.42(\mathrm{dd}, J=11.6,6.6 \mathrm{~Hz}), 4.62(\mathrm{dd}, J=11.6,2.8 \mathrm{~Hz}), 3.91(\mathrm{td}, J=\right.$ 2.7, $6.7 \mathrm{~Hz}), 3.65(\mathrm{td}, J=2.8,6.9 \mathrm{~Hz}), 3.80(\mathrm{dd}, J=13.8,11.4 \mathrm{~Hz}), 3.67(\mathrm{dd}, J=13.8,5.4 \mathrm{~Hz})]$, and two methyls $\left[\delta_{\mathrm{H}} 2.27(\mathrm{~s}), 2.52(\mathrm{~d}, J=7.7 \mathrm{~Hz})\right]$. The ${ }^{13} \mathrm{C}$ NMR data (Table 2) displayed 19 carbon resonances, comprising 12 aromatic carbons, a carbonyl $\left(\delta_{C} 172.4\right)$, two methyls $\left(\delta_{C} 21.4,24.5\right)$, two methylenes $\left(\delta_{\mathrm{C}} 64.5,68.1\right)$ and two methines $\left(\delta_{\mathrm{C}} 71.0,73.7\right)$. A meta-location of protons $\mathrm{H}-2, \mathrm{H}-4, \mathrm{H}-6, \mathrm{H}-8$ and $\mathrm{H}-12$ were confirmed by the coupling constants of $\mathrm{H}-2\left[\delta_{\mathrm{H}} 6.29(1 \mathrm{H}, \mathrm{t}, \mathrm{J}=2.2 \mathrm{~Hz})\right], \mathrm{H}-8\left[\delta_{\mathrm{H}} 6.24(1 \mathrm{H}, \mathrm{d}\right.$, $J=2.5 \mathrm{~Hz})]$, and $\mathrm{H}-12\left[\delta_{\mathrm{H}} 6.36(1 \mathrm{H}, \mathrm{d}, J=2.5 \mathrm{~Hz})\right]$. The mutual HMBC correlations between $\mathrm{CH}-2$, $\mathrm{CH}-4$ and $\mathrm{CH}-6$, and HMBC correlations from $\mathrm{H}-2$ to $\mathrm{C}-1$ and $\mathrm{C}-3$, from $\mathrm{H}-4$ to $\mathrm{C}-3, \mathrm{C}-5$ and $\mathrm{C}-18$, from $\mathrm{H}-6$ to $\mathrm{C}-1, \mathrm{C}-5$, and C-18, and from $\mathrm{H}-18$ to C-4 and C-6 indicated the existence of an orcinolic unit in 2. The ortho-orselinic acid moiety in 2 was determined based on the HMBC correlations of H-8/C-7, C-9, C-10, and C-12, of H-12/C-7, C-8, C-10 and C-19, of H-19/C-10, C-11, C-12 and C-17 (Figure 2). The COSY correlations of H-13/H-14; H-14/H-15; H-15/H-16 revealed a butane-1,2,3,4-tetrol moiety in 2. Moreover, the butane-1,2,3,4-tetrol moiety was connected to ortho-orselinic moiety through C-13-O-C-9 by the HMBC correlation of H-13/C-17. The butane-1,2,3,4-tetrol moiety was assigned to be erythritol by comparison of $\mathrm{H}-2$ and $\mathrm{H}-3$ coupling constants $(\mathrm{J}=6.8 \mathrm{~Hz})$ with the rule reported by Hawkes [23]. Furthermore, the absolute configuration of 2 was established as $2 S, 3 R$ by comparing the optical rotation of $2(-7.4)$ with that of $(2 S, 3 R)$-montagnetol $(-10.1)[24,25]$. 


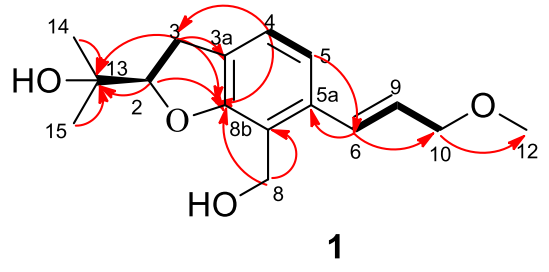

- COSY

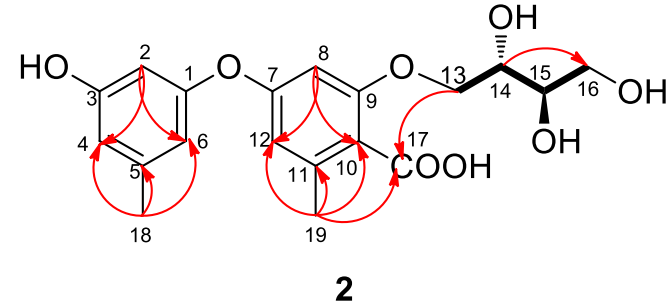

2

Figure 2. Key HMBC, COSY correlations of $\mathbf{1}$ and 2.

Table 2. ${ }^{1} \mathrm{H}$ and ${ }^{13} \mathrm{C}$ NMR data of compound $2\left(600 \mathrm{MHz}, 150 \mathrm{MHz}\right.$, in $\left.\mathrm{CD}_{3} \mathrm{OD}\right)$.

\begin{tabular}{ccc}
\hline Position & $\delta_{\mathbf{C}}$ & $\delta_{\mathbf{H}}(\boldsymbol{J}$ in $\mathbf{H z})$ \\
\hline 1 & 157.4 & \\
2 & 105.7 & $6.29(1 \mathrm{H}, \mathrm{t}, 2.2)$ \\
3 & 159.9 & $6.49(1 \mathrm{H}, \mathrm{t}, 1.6)$ \\
4 & 113.6 & $6.37(1 \mathrm{H}, \mathrm{s})$ \\
5 & 142.1 & \\
6 & 113.1 & $6.24(1 \mathrm{H}, \mathrm{d}, 2.5)$ \\
7 & 163.5 & \\
8 & 103.7 & \\
9 & 164.5 & $6.36(1 \mathrm{H}, \mathrm{d}, 2.5)$ \\
10 & 109.5 & $4.42(1 \mathrm{H}, \mathrm{dd}, 11.6,6.6)$ \\
11 & 144.6 & $3.62(1 \mathrm{H}, \mathrm{dd}, 11.6,2.8)$ \\
12 & 113.4 & $3.65(1 \mathrm{H}, \mathrm{td}, 2.8,6.7)$ \\
13 & 68.1 & $2.8,6.9)$ \\
14 & 71.0 & $2.80(1 \mathrm{H}, \mathrm{dd}, 13.8,11.4)$ \\
15 & 73.7 & \\
16 & 64.5 & $2.67(3 \mathrm{H}, \mathrm{dd}, 13.8,5.4)$ \\
17 & 172.4 & \\
18 & 21.4 & \\
19 & 24.5 & \\
& &
\end{tabular}

Furthermore, seven known compounds 3-9 were identified as diorcinol-3-O- $\alpha$-D-ribofuranoside (3) [15], 4-carbglyceryl-3,3'-dihydroxy-5,5'-dimethyldiphenyl ether (4) [16], gibellulin B (5) [17], daldinin C (6) [18], 12-hydroxysydonic acid (7) [19], (+)-sydonic acid (8) [20], and oxalicumone A (9) [21] by comparison of their spectral data with those reported in the literature.

\subsection{Biological Activities}

The antibacterial activity was tested using sequential 2-fold serial dilutions of each compound in DMSO to provide 10 concentrations for all of the assays [26]. Four pathogenic bacteria, including $V$. parahaemolyticus, V. harveyi, E. coli, and S. aureus, were used, and the chloramphenicol was used as positive control. The results (Table 3 ) revealed that $\mathbf{9}$ showed weak inhibitory activity against $E$. coli with an MIC value of $75.4 \mu \mathrm{M}$. 7 had significant inhibitory activity against $S$. aureus (MIC value, $3.54 \mu \mathrm{M})$. Other compounds had no significant activity against four pathogenic bacteria.

Compounds 1-9 were also evaluated for their cytotoxic activities against seven human-derived cancer cell lines CCRF-CEM (human acute lymphoblastic leukemia T lymphocyte), K562 (human chronic myeloid leukemia cell), BGC823 (human gastric adenocarcinoma), AGS (human gastric adenocarcinoma),HCT-116 (human colon cancer cell), MDA-MB-453 (human breast cancer cell), and COR-L23 (human lung cancer cell) using the 3-(4, 5-dimethylthiazol-2-yl)-2, 5-diphenyltetrazolium bromide (MTT) assay and following the procedure previously described [27]. None of the compounds 
showed cytotoxicity against the BGC823 and AGS. Compound 1, 2, 5, and 6 exhibited weak effects against human cancer cell lines HCT-116 (1), CCRF-CEM (2), K562 (2), MDA-MB-453 (5), and COR-L23 (6). Compound 9 exhibited pronounced cytotoxicity against CCRF-CEM cell and K562 cell with the $\mathrm{IC}_{50}$ values of $1.22 \pm 0.045$ and $9.58 \pm 0.19 \mu \mathrm{M}$, respectively. The results (Table 4) revealed that these compounds were found to display highly selective antibacterial activities and cytotoxicities.

Table 3. Antibacterial activities of compounds 1, 2, 5, 7 and 9.

\begin{tabular}{ccccc}
\hline \multirow{2}{*}{ Compounds } & \multicolumn{5}{c}{ MIC $(\mu \mathrm{M})$} \\
\cline { 2 - 5 } & V. parahaemolyticus & V. harveyi & E. coli & S. aureus \\
\hline $\mathbf{1}$ & $/$ & $/$ & 230 & 460 \\
$\mathbf{2}$ & $/$ & $/$ & $/$ & 170 \\
$\mathbf{5}$ & $/$ & $/$ & $/$ & 492 \\
$\mathbf{7}$ & 453 & $/$ & $/$ & 3.54 \\
$\mathbf{9}$ & $/$ & 301 & 75.4 & $/$ \\
Chloramphenicol & 1.42 & 1.07 & 1.25 & 0.91 \\
\hline \multicolumn{5}{c}{}
\end{tabular}

Table 4. Cytotoxicities of compounds 1, 2, 5, 6 and 9.

\begin{tabular}{|c|c|c|c|c|c|}
\hline \multirow{2}{*}{ Compound } & \multicolumn{5}{|c|}{$\mathrm{IC}_{50}(\mu \mathrm{M})$} \\
\hline & CCRF-CEM & K562 & НСТ-116 & MDA-MB-453 & COR-L23 \\
\hline 1 & 1 & 1 & $27.63 \pm 1.25$ & l & 1 \\
\hline 2 & $19.73 \pm 0.98$ & $29.28 \pm 0.75$ & 1 & / & I \\
\hline 5 & I & 1 & / & / & $29.17 \pm 0.98$ \\
\hline 6 & I & I & I & $22.58 \pm 0.42$ & I \\
\hline 9 & $1.22 \pm 0.05$ & $10.58 \pm 0.19$ & / & 1 & / \\
\hline Chidamide & $0.97 \pm 0.1$ & $1.87 \pm 0.29$ & & & \\
\hline 5-Fluorouracil & & & $2.7 \pm 0.54$ & $1.58 \pm 0.42$ & $6.62 \pm 0.68$ \\
\hline
\end{tabular}

\section{Materials and Methods}

\subsection{General Experimental Procedures}

Optical rotations were measured with a P-2000 digital polarimeter (JASCO, Hachioji, Japan). UV spectra were obtained with a NADE Evolution 201 spectrophotometer (ThermoFisher, Waltham, MA, USA). IR spectra were recorded on a Nicolet iS5 IR spectrometer (ThermoFisher, Waltham, MA, USA). ${ }^{1} \mathrm{H}-\mathrm{NMR}(600 \mathrm{MHz})$ and ${ }^{13} \mathrm{C}(150 \mathrm{MHz})$ spectra were measured with a Varian $600 \mathrm{MHz}$ (Palo Alto, CA, USA) spectrometer. Chemical shifts were reported in ppm, while using the signals of the residual solvent as internal reference $\left(\delta_{\mathrm{H}} 3.31\right.$ and $\delta_{\mathrm{C}} 49.0$ for $\mathrm{CD}_{3} \mathrm{OD}, \delta_{\mathrm{H}} 7.26$ and $\delta_{\mathrm{C}} 77.1$ for $\mathrm{CDCl}_{3}$ ). HRESIMS data were recorded on an Agilent Technologies 6520 Accurate Mass Q-TOF LC/MS spectrometer (Agilent Technologies, Santa Clara, CA, USA). Medium-pressure liquid chromatography (MPLC) was performed on a FLEXA Purification System (Agela Technologies, Tianjin, China) using a ODS column. Column chromatography (CC) was carried out with silica gel (200-300 mesh, Qingdao Marine Chemical Inc. Qingdao, PR China) and Sephadex LH20 (Amersham Biosciences, Piscataway, NJ, USA). CC fractions were analyzed by TLC (silica gel GF254, Qingdao Marine Chemical Factory, Qingdao, China). Semi-preparative HPLC (Waters 600, Milford, MA, USA) equipped with a Waters 2996 detector and a $C_{18}$ column $(250 \mathrm{~mm} \times 20 \mathrm{~mm}$ ID, $5 \mu \mathrm{m}$; YMC Co. Ltd., Tokyo, Japan). 


\subsection{Fungal Material}

The fungal strain, Aspergillus sp. LS34, was isolated from the sponge Haliclona sp. collected at Lingshui, Hainan Province, China. It was identified as Aspergillus sp. according to morphological and molecular (ITS rDNA sequence) analyses (GenBank accession ID: EU645721, 99\% similarity). A voucher specimen (No. LS34) was deposited in the potato dextrose agar (PDA) medium (potato $200 \mathrm{~g}$, dextrose $20 \mathrm{~g} / \mathrm{L}$, sea salt $35 \mathrm{~g} / \mathrm{L}$ and agarose $20 \mathrm{~g} / \mathrm{L}$ ) at Ningbo University, Ningbo, China.

\subsection{Fermentation}

After being maintained on PDA medium for 7 days, the strain LS34 was inoculated into $1 \mathrm{~L}$ Erlenmeyer flasks that contained $200 \mathrm{~mL}$ of PDB medium (potato $200 \mathrm{~g}$, dextrose $20 \mathrm{~g} / \mathrm{L}$ and sea salt $35 \mathrm{~g} / \mathrm{L}$ ) at $28^{\circ} \mathrm{C}$ for 2 days on a rotary shake at $200 \mathrm{rpm}$. Then, the seed culture was inoculated into two media including potato dextrose broth (PDB) medium containing (potato $200 \mathrm{~g}$, dextrose $20 \mathrm{~g} / \mathrm{L}$ and sea salt $35 \mathrm{~g} / \mathrm{L}, 30$ flasks $)$ on a rotatory shaker $(180 \mathrm{rpm})$ at $28^{\circ} \mathrm{C}$ for 12 days, and solid rice medium (rice $120 \mathrm{~g}$ and sea water $180 \mathrm{~mL}, 30$ flasks) at $28^{\circ} \mathrm{C}$ for 30 days under static conditions.

\subsection{Extraction and Isolation}

The PDB fermentation broth was extracted using EtOAc to afford crude extract ( $4.5 \mathrm{~g}$ ), which was subjected to gel filtration on a Sephadex LH-20 column, eluted with $\mathrm{CH}_{3} \mathrm{OH}$ and $\mathrm{CH}_{2} \mathrm{Cl}_{2}(1: 1, v / v)$, affording three fractions (Fr. 1-3). Fr. 2 (1.9 g) was subjected to vacuum liquid chromatography (VLC) on a silica gel column $(6 \times 15 \mathrm{~cm}, 200-300$ mesh) eluting with mixtures of solvents with increasing polarity: hexane/EtOAc (from 20:1 to 0:1 (v/v)) to yield four subfractions (Fr.2.A-D), then EtOAc/MeOH (from 1:1 to 0:1 $(v / v)$ ) to yield two fractions (Fr.2.E-F). Fr.2.D (130 mg) was further separated by reversed-phase MPLC $\left(30-100 \% \mathrm{MeOH} / \mathrm{H}_{2} \mathrm{O}, 120 \mathrm{~min}\right.$, flow rate $\left.20 \mathrm{~mL} / \mathrm{min}\right)$ to get four subfractions (Fr.2.D.1-4). Furthermore, subtraction Fr.2.D.2 was purified by semipreparative RP-HPLC $(2.0 \mathrm{~mL} / \mathrm{min}$; $35 \% \mathrm{MeCN}$ in $\mathrm{H}_{2} \mathrm{O}$ ) to yield 6 ( $t_{\mathrm{R}} 20.2 \mathrm{~min}, 3.6 \mathrm{mg}$ ) and 9 ( $t_{\mathrm{R}} 32.4 \mathrm{~min}, 4.2 \mathrm{mg}$ ). Subfraction Fr.2.D.3 was further separated by semipreparative RP-HPLC $\left(2.0 \mathrm{~mL} / \mathrm{min} ; 40 \% \mathrm{MeCN}\right.$ in $\left.\mathrm{H}_{2} \mathrm{O}\right)$ to obtain 7 $\left(t_{\mathrm{R}} 25.8 \mathrm{~min}, 2.7 \mathrm{mg}\right.$ ) and $8\left(t_{\mathrm{R}} 34.7 \mathrm{~min}, 4.9 \mathrm{mg}\right)$.

The rice fermentation was exhaustively extracted with $\mathrm{MeOH}$ three times in an ultrasonic bath at $40{ }^{\circ} \mathrm{C}$ for $15 \mathrm{~min}$ and filtered, then $\mathrm{MeOH}$ layers were combined and evaporated. The extract was suspended in $1 \mathrm{~L} \mathrm{H}_{2} \mathrm{O}$ and extracted three times with EtOAc, after which it was filtered and evaporated in vacuo to obtain crude extracts $(5.3 \mathrm{~g})$. The crude extract was further separated by CC on Sephadex LH-20 eluting with $\mathrm{CH}_{3} \mathrm{OH}$ and $\mathrm{CH}_{2} \mathrm{Cl}_{2}(1: 1, v / v)$ to afford three fractions (Fr. A-C). Fr. B was subjected to VLC over silica gel using gradients of hexane/EtOAc (from 20:1 to 0:1 (v/v)) to yield four subfractions (Fr.B.1-4), then EtOAc/MeOH (from 1:1 to 0:1 (v/v)) to yield two fractions (Fr.B.5-6). Fr.B.4 was further separated by reversed-phase MPLC ( $30-100 \% \mathrm{MeOH} / \mathrm{H}_{2} \mathrm{O}, 120 \mathrm{~min}$, flow rate $\left.20 \mathrm{~mL} / \mathrm{min}\right)$ to afford three fractions (Fr.B.4.A-C). Furthermore, using semi-preparative RP-HPLC and elution with 30\% MeCN, compounds $3\left(t_{\mathrm{R}} 27.5 \mathrm{~min}, 3.2 \mathrm{mg}\right)$ and $4\left(t_{\mathrm{R}} 36.9 \mathrm{~min}, 7.7 \mathrm{mg}\right)$ were isolated from Fr.B.4.B. Fr.B.5 was further separated by MPLC $\left(30-100 \% \mathrm{MeOH} / \mathrm{H}_{2} \mathrm{O}, 120 \mathrm{~min}\right.$, flow rate $\left.20 \mathrm{~mL} / \mathrm{min}\right)$ to obtain five fractions (Fr.B.5.A-E). Subsequently, the subfraction Fr.B.5.B was purified by semipreparative RP-HPLC ( $2.0 \mathrm{~mL} / \mathrm{min} ; 30 \% \mathrm{MeCN}$ in $\mathrm{H}_{2} \mathrm{O}$ ) to yield $2\left(t_{\mathrm{R}} 20.2 \mathrm{~min}, 2.2 \mathrm{mg}\right)$ and $5\left(t_{\mathrm{R}} 24.1 \mathrm{~min}, 6.7 \mathrm{mg}\right)$. Subfraction Fr.B.5.C was purified by semipreparative RP-HPLC $\left(2.0 \mathrm{~mL} / \mathrm{min} ; 40 \% \mathrm{MeCN}\right.$ in $\left.\mathrm{H}_{2} \mathrm{O}\right)$ to afford $1\left(t_{\mathrm{R}} 27.3 \mathrm{~min}, 3.5 \mathrm{mg}\right)$.

Asperspin A: White powder; molecular formula $\mathrm{C}_{16} \mathrm{H}_{22} \mathrm{O}_{4} ;[\alpha]_{\mathrm{D}}^{25}-4.0(c 0.1, \mathrm{MeOH}) ; \mathrm{UV}(\mathrm{MeOH})$ $\lambda_{\max }(\log \varepsilon) 220$ (4.04), 305 (3.35) nm; IR (KBr) $v_{\max } 3390,2919,1645,1437,968 \mathrm{~cm}^{-1} ;{ }^{13} \mathrm{C}$ and ${ }^{1} \mathrm{H}$ NMR data (in $\mathrm{CDCl}_{3}$ ), see Table 1, HRESIMS $\mathrm{m} / z 277.1440[\mathrm{M}-\mathrm{H}]^{-}$(calcd. for $\mathrm{C}_{16} \mathrm{H}_{21} \mathrm{O}_{4}$, 277.1445).

Asperther A: Yellow oil; molecular formula $\mathrm{C}_{19} \mathrm{H}_{22} \mathrm{O}_{8} ;[\alpha]_{\mathrm{D}}^{25}-7.4(c 0.1, \mathrm{MeOH}) ; \mathrm{UV}(\mathrm{MeOH}) \lambda_{\max }$ (log ع) 204 (4.21), 218 (4.65) nm; IR (KBr) $v_{\max }$ 3356, 1647, 1598, 1459, 1318, 1258, 1205, 1161, $1029 \mathrm{~cm}^{-1}$; ${ }^{13} \mathrm{C}$ and ${ }^{1} \mathrm{H}$ NMR data (in $\mathrm{CD}_{3} \mathrm{OD}$ ), see Table 2, HRESIMS $\mathrm{m} / \mathrm{z} 377.1237[\mathrm{M}-\mathrm{H}]^{-}$(calcd. for $\mathrm{C}_{19} \mathrm{H}_{21} \mathrm{O}_{8}$, 377.1242). 


\subsection{Biological Assay}

The antibacterial assay was conducted using the conventional broth dilution method [26]. Briefly, a series of different concentrations of the test compounds were dissolved to DMSO, using sequential 2 -fold serial dilutions to obtain different concentrations. Each concentration of test compounds was added to 96 -well plates, then bacterial suspension $\left(10^{6} \mathrm{CFU}\right.$ per milliliter) was added to the plate and was kept at $28^{\circ} \mathrm{C}$ for $48 \mathrm{~h}$. All the procedures in the assay were performed in triplicates. The minimum inhibitory concentration (MIC) for $V$ parahaemolyticus, $V$ harveyi, E. coli, and S. aureus were determined according to the concentration that inhibited visible growth of pathogen. The cytotoxic activities of compounds 1-9 against human cancer cell lines were assessed by the MTT method, as described previously [27]. In brief, the cell suspension $\left(1 \times 10^{5} / \mathrm{mL}\right)$ was inoculated into 96-well plates and was kept at $37^{\circ} \mathrm{C}$ for $12 \mathrm{~h}$. Then each well was added with sample solvent and further cultured at $37^{\circ} \mathrm{C}$ for $48 \mathrm{~h}$. Subsequently, MTT was added to each well and incubated at $37^{\circ} \mathrm{C}$ for $4 \mathrm{~h}$. After removing the medium, the cells were lysed with 20\% SDS-50\% DMF. Absorbance of each well was measured using a 96-well microplate reader at $595 \mathrm{~nm}$ for assessment of cell growth. Chidamide was used as a positive control.

\section{Conclusions}

Based on the OSMAC culture strategy, the chemical investigation of marine-derived fungus Aspergillus sp. LS34 resulted in isolation of isolation of two new compounds $\mathbf{1}$ and $\mathbf{2}$ together with three known compounds 3-5 from solid rice medium, and four known compounds 6-9 from the PDB medium. Obviously, the OSMAC strategy represented a powerful way to induce new metabolites from microorganisms. Diphenyl ethers 2-5 and their derivatives have been extensively investigated and exhibited variability due to the diversity and location of hydroxyl group and the side chain. Compound 3 was a rare diphenyl ether derivative containing a D-ribofuranose fragment. Notably, compound 7 displayed pronounced antibacterial activity against $S$. aureus. Compound 9 exhibited significant cytotoxic activity against human cancer cell lines CCRF-CEM and K562.

Supplementary Materials: The following are available online at http://www.mdpi.com/1660-3397/17/5/283/s1, Figures S1-S34: HRESIMS, HPLC chromatograms, 1D and 2D NMR, IR, or UV spectra of 1-9.

Author Contributions: W.L., L.D. and H.J. conceived and designed the experiments. W.L., L.D., N.W. and J.X. performed the experiments. L.D., B.Z., N.W., W.Z., S.H. and B.W. analyzed the data. W.L., and L.D. wrote the paper.

Funding: This study was supported by the National Key Research and Development Program of China (2018YFC0310900), the National Natural Science Foundation of China (41776168, 41706167), Ningbo Public Service Platform for High-Value Utilization of Marine Biological Resources (NBHY-2017-P2), Zhejiang Provincial Public Welfare Technology Program (LGC19B020002), the Natural Science Foundation of Ningbo (2018A610303, 2018A610320), Ningbo Sci. \& Tech. Projects for Common Wealth (2017C10016), the National 111 Project of China (D16013), the Li Dak Sum Yip Yio Chin Kenneth Li Marine Biopharmaceutical Development Fund, and the K.C. Wong Magna Fund in Ningbo University.

Conflicts of Interest: The authors declare no conflict of interest.

\section{References}

1. Zhao, D.; Shao, C.; Gan, L.; Wang, M.; Wang, C. Chromone derivatives from a sponge-derived strain of the fungus Corynespora cassiicola. J. Nat. Prod. 2015, 78, 286-293. [CrossRef] [PubMed]

2. Liu, M.; Sun, W.; Wang, J.; Yan, H.; Zhang, J.; Li, F.; Qi, C.; Zhu, H.; Xue, Y.; Hu, Z. Bioactive secondary metabolites from the marine-associated fungus Aspergillus terreus. Bioorg. Chem. 2018, 80, 525-530. [CrossRef]

3. Fang, F.; Zhao, J.; Ding, L.; Huang, C.; Naman, C.B.; He, S.; Wu, B.; Zhu, P.; Luo, Q.; Gerwick, W.H. 5-Hydroxycyclopenicillone, a new $\beta$-amyloid fibrillization inhibitor from a sponge-derived fungus Trichoderma sp. HPQJ-34. Mar. Drugs 2017, 15, 260. [CrossRef]

4. Moghadamtousi, S.Z.; Nikzad, S.; Kadir, H.A.; Abubakar, S.; Zandi, K. Potential antiviral agents from marine fungi: an overview. Mar. Drugs 2015, 13, 4520-4538. [CrossRef] [PubMed] 
5. Wu, B.; Wu, X.; Sun, M.; Li, M. Two novel tyrosinase inhibitory sesquiterpenes induced by $\mathrm{CuCl}_{2}$ from a marine-derived fungus Pestalotiopsis sp. Z233. Mar. Drugs 2013, 11, 2713-2721. [CrossRef] [PubMed]

6. Wang, W.; Li, D.; Li, Y.; Hua, H.; Ma, E.; Li, Z. Caryophyllene sesquiterpenes from the marine-derived fungus Ascotricha sp. ZJ-M-5 by the one strain-many compounds startegy. J. Nat. Prod. 2014, 77, 1367-1371. [CrossRef] [PubMed]

7. Zhou, Y.; Ju, G.; Xiao, L.; Zhang, X.; Du, F. Cyclodepsipeptides and sesquiterpenes from marine-derived fungus Trichothecium roseum and their biological functions. Mar. Drugs 2018, 16, 519. [CrossRef] [PubMed]

8. Kang, H.; Zhang, H.; Zhong, M.; Ma, L.; Liu, D.; Liu, W.; Ren, H. Potential antiviral xanthones from a Coastal Saline Soil fungus Aspergillus iizukae. Mar. Drugs 2018, 16, 449. [CrossRef] [PubMed]

9. Yu, H.; Wang, X.; Zhang, Y.; Xu, W.; Zhang, J.; Zhou, X.; Lu, X.; Liu, X.; Jiao, B. Libertellenones O-S and Eutypellenones A and B, pimarane diterpene derivatives from the Arctic fungus Eutypella sp. D-1. J. Nat. Prod. 2018, 81, 1553-1560. [CrossRef]

10. Bugni, T.S.; Ireland, C.M. Marine-derived fungi: A chemically and biologically diverse group of microorganisms. Nat. Prod. Rep. 2004, 21, 143-163. [CrossRef] [PubMed]

11. Hamann, M.T.; Scheuer, P.J.; Dunbar, D.C.; Otto, C.S. Kahalalides: Bioactive peptides from a marine mollusk Elysia rufescens and its algal diet Bryopsis sp. J. Org. Chem. 1996, 61, 6594-6600. [CrossRef]

12. Wu, Z.; Wang, Y.; Liu, D.; Proksch, P.; Yu, S.; Lin, W. Antioxidative phenolic compounds from a marine-derived fungus Aspergillus versicolor. Tetrahedron 2016, 72, 50-57. [CrossRef]

13. Wang, W.; Chen, R.; Luo, Z.; Wang, W.; Chen, J. Antimicrobial activity and molecular docking studies of a novel anthraquinone from a marine-derived fungus Aspergillus versicolor. Nat. Prod. Rep. 2017, 32, 558-563. [CrossRef] [PubMed]

14. Tan, Y.; Yang, B.; Lin, X.; Luo, X.; Pang, X.; Tang, L.; Liu, Y.; Li, X.; Zhou, X. Nitrobenzoyl sesquiterpenoids with cytotoxic activities from a marine-derived Aspergillus ochraceus fungus. J. Nat. Prod. 2018, 81, 92-97. [CrossRef]

15. Wang, Y.; Mou, Y.; Dong, Y.; Wu, Y.; Liu, B.; Bai, J.; Yan, D.; Zhang, L.; Feng, D.; Pei, Y.; Hu, Y. Diphenyl ethers from a marine-derived Aspergillus sydowii. Mar. Drugs 2018, 16, 451. [CrossRef]

16. Huang, Z.; Nong, X.; Ren, Z.; Wang, J.; Zhang, X.; Qi, S. Anti-HSV-1, antioxidant and antifouling phenolic compounds from the deep-sea-derived fungus Aspergillus versicolor SCSIO 41502. Bioorg. Med. Chem. Lett. 2017, 27, 787-791. [CrossRef]

17. Li, X.; Xia, Z.; Tang, J.; Wu, J.; Tong, J.; Li, M.; Ju, J.; Chen, H.; Wang, L. Identification and biological evaluation of secondary metabolites from marine derived fungi-Aspergillus sp. SCSIOW3, cultivated in the presence of epigenetic modifying agents. Molecules 2017, 22, 1302. [CrossRef]

18. Shao, H.; Qin, X.; Dong, Z.; Zhang, H.; Liu, J. Induced daldinin A, B, C with a new skeleton from cultures of the ascomycete Daldinia concentrica. J. Antibiot. 2008, 61, 115-119. [CrossRef]

19. Yurchenko, A.A.; Smetanina, O.F.; Kalinovsky, A.I.; Kirichuk, N.N.; Pivkin, M.V.; Ivanets, E.V.; Yurchenko, E.A.; Afiyatullov, S.S. New metabolites from a marine sediment-derived fungus, Aspergillus carneus. Nat. Prod. Commun. 2015, 10, 1247-1250.

20. Zhen, C.; Shao, C.; Wang, K.; Zhao, D.; Wang, Y.; Wang, C. Secondary metabolites and their bioactivities of a soft coral-derived fungus Aspergillus versicolor (ZJ-2008015). Chin. J. Mar. Drugs 2012, 31, 7-13.

21. Sun, Y.; Bao, J.; Liu, K.; Zhang, X.; He, F.; Wang, Y.; Nong, X.; Qi, S. Cytotoxic dihydrothiophene-condensed chromones from the marine-derived fungus Penicillium oxalicum. Planta Med. 2013, 79, 1474-1479. [CrossRef] [PubMed]

22. Kawase, Y.; Yamaguchi, S.; Inoue, O.; Sannomiya, M.; Kawabe, K. The syntheses and absolute configurations of fomannoxin, (-)-5-acetyl-2-(1-hydroxymethylvinyl)-2,3-dihydrobenzofuran, and anodendroic acid. Chem. Lett. 1980, 9, 1581-1584. [CrossRef]

23. Hawkes, G.E.; Lewis, D. ${ }^{1} \mathrm{H}$ nuclear magnetic resonance spectra and conformations of alditols in deuterium oxide. J. Chem. Soc. Perkin Trans. 1984, 2, 2073-2078. [CrossRef]

24. Basset, J.F.; Leslie, C.; Hamprecht, D.; White, A.J.P.; Barrett, A.G.M. Studies on the esorcylates: biomimetic total syntheses of (+)-montagnetol and (+)-erythrin. Tetrahedron Lett. 2010, 51, 783-785. [CrossRef]

25. Kumbaraic, V.; Gunduz, H.; Karadeniz, M. Facile syntheses of (-)-montagnetol and (-)-erythrin. Tetrahedron Lett. 2013, 54, 6328-6330. [CrossRef] 
26. Rodríguez-Tudela, J.L.; Barchiesi, F.; Bille, J.; Chryssanthou, E.; Cuenca-Estrella, M.; Denning, D.; Donnelly, J.P.; Dupont, B.; Fegeler, W.; Moore, C. Method for the determination of minimum inhibitory concentration (MIC) by broth dilution of fermentative yeasts. Clin. Microbiol. Infect. 2003, 9, 1-8.

27. George, F.; John, A.T. In vitro cytotoxicity assays: Comparison of LDH, neutral red, MTT and protein assay in hepatoma cell lines following exposure to cadmium chloride. Toxicol. Lett. 2006, 160, 171-177.

(C) 2019 by the authors. Licensee MDPI, Basel, Switzerland. This article is an open access article distributed under the terms and conditions of the Creative Commons Attribution (CC BY) license (http://creativecommons.org/licenses/by/4.0/). 